\title{
Growth of Nile Tilapia Oreochromis niloticus Fed Diets with Different Levels of Proteins of Yeast
}

\author{
Vandir Medri $^{*}$, Waldir Medri ${ }^{1}$ and Mauro Caetano Filho ${ }^{2}$ \\ ${ }^{I}$ Departamento de Estatística Matemática Aplicada; Campus Universitário; Universidade Estadual de Londrina; \\ 86510-990; Londrina - PR - Brasil. ${ }^{2}$ Departamento de Biologia Animal e Vegetal; Campus Universitário; \\ Universidade Estadual de Londrina; 86.510-990; Londrina - PR - Brasil
}

\begin{abstract}
This experiment was based on observations of 72 juveniles of Nile tilapia (Oreochromis niloticus), sexually reverted with an initial mean weight of $37.27 \pm 4.92 \mathrm{~g}$, distributed in 12 cages of $100 \mathrm{l}$ to evaluate the effects of the yeast inclusion as proteins source in the diet. The fishes were distributed in a completely randomized design with four treatments $(0 ; 20 ; 40$; and $60 \%)$ of yeast protein in substitution to the protein of traditional sources with three repetitions. Effects of the treatments were not observed $(p>0.05)$ on the survival and to food conversion. It was observed a quadratic effect on weight gain $\left(Y=73.39+0.173 X-0.0034 X^{2} ; R^{2}=0.9986\right)$. It was concluded the best level of yeast inclusion as source proteins in the diet for reversed Nile tilapia juvenile was $25.44 \%$.
\end{abstract}

Key words: yeast, cages, tilapia

\section{INTRODUCTION}

Among the species of fish used for aquiculture, the tilapias, over all of the class Oreochromis are some of the most promising in the countries of tropical or subtropical climate (Campos-Ramos et al., 2003; Desprez et al., 2003). With the exception of the carp, the tilapias are the fishes more cultivated in the world (Lovshin, 1997; Alceste and Jorry, 1998) including Brazil (Lovshin and Cyrino, 1998; Bombardelli and Hayashi, 2005).

The prominence of the species is comes to its qualities, such as rusticity (Wu et al., 1995; Hayashi, 1995), capacity to survive for the adverse ambient conditions as low level of oxigen and high ammonia levels dissolved in the water, fast growth, good conversion alimentary and consumption of artificial ration since the larval phase (Alceste and Jorry, 1998). It is emphasized also for adjusting industry of filleting, due to lack of thorns muscle in "Y" (Furuya, 2004); to have great acceptance in the consumer market, for the organoleptics characteristics of its fillet, and show up well appreciated in fish-pay.

The protein foods are responsible for the largest fraction of the cost of the ration in the intensive and half-intensive pisciculture (Boscolo et al., 2001; Furuya, 2001), because, besides composing great amount in the formulations (Kikuchi, 1999), show greater cost that food energy. The increase in the productivity requires the use of complete rations, therefore the natural food not capable to take care of the requirements of the fish, mainly when created in tank-net and "raceways", where the raised biomass for area and the deficiencies or not balanced of nutrients can cause losses of

\footnotetext{
* Author for correspondence: vandir@uel.br
} 
productivity and, consequently, minor economic return (Furuya, 2001).

Alternative protein foods, such as the fish flour has been studied with the objective to reduce the cost of the rations (Oliveira et al., 1997; Refstie et al., 1999; Booth et al., 2001; Siddhuraju and Becker, 2001, Meurer et al., 2003). However, one of the problems found for the use of this material is the lack of information of the values of digestibility of its nutrients (Mukhopadhyay and Ray, 1997).

The protein sources of vegetable are cheaper than those of animal origin, but have to amino acid balance inappropriate for the application of fish (El-Dahhar and El-Shazly, 1993), besides the presence of non-starch polysaccharides that can influence in a negative way in the performance of the same (Meurer and Hayashi, 2003). However, the Nile tilapia may, from the stage of fingerling, to use of vegetable protein sources, as the single source of protein, without problems related to performance (Boscolo et al., 2001; Meurer, 2002). The dried yeast spray (LS) a material produced for the sugar alcohol, composed of cells of yeast (Saccharomyces $s p$.) Obtained from the fermentation broth of sugar cane in the production of alcohol (Scapinello, et al., 1996; Furuya, et al., 2000), for the process of drying spray-dryer. It has its chemical composition highly variable depending on the method of production, washing and drying (Scapinello et al., 1997; Furuya, et al., 2000). However, about 20 to $30 \%$ of total nitrogen can come from non-protein nitrogen, such as nucleic acids (Butolo, 1997), can be a source of super-estimate of the protein (Meurer et al., 2000). The dried yeast (Saccharomyces cerevisiae), in addition to a high protein level, has a high quality protein for your balance in amino acids (Ghiraldini and Rossell, 1997) even though levels of vitamins $\mathrm{A}$ and $\mathrm{C}$ are reduced, they are rich in the $\mathrm{B}$ complex vitamins (Butolo, 1997), stands out the levels of thiamine, reboflavine, niacin and acid pantotenic.

Some authors found that the ingredients of the diet could determine its ingestion or rejection, or even the quality to be consumed. Pereira da Silva and Pezzato (2000) studied the behavior response of Nile tilapia with respect to different ingredients commonly used in diet formulations, showing that sugar-cane yeast presented medium attractpalatability.

It is necessary to make effort to convince the industrial doesn't the quality of a sugarcane subproduct, such as the yeast from the fermentation process. Yeast could be a value product, but its importance has been not recognized in the market, here the industries are not stimulated to produce it.

The aim of this work was to evaluate the effect of yeast on the growth of Nile tilapia fed with $0 \%$ (control), 20, 40 and 60\% (tests) of distillery yeast protein substituting the traditional source of protein.

\section{MATERIALS AND METHODS}

The experiment was conducted in the Station of Pisciculture of the State University of Londrina, Paraná, during the period of 112 days (17/05 a 06/09/02). The experiment was based on observations of 72 juveniles of Nile tilapia (Oreochromis niloticus), with an initial mean weight of $37.27 \pm 4.92 \mathrm{~g}$. The fishes were reversed by the supply of rations with $60 \mathrm{mg} / \mathrm{Kg}$ of diet of the male hormone $17 \alpha$-metiltestosterone, during a period of 30 days, obtained by the Fish Breeding Station of the Animal and Vegetal Department of Biology Science Center of the State University of Londrina.

Four rations with 0\% (control=Pirá tropical), 20\%, $40 \%$ and $60 \%$ (test) of yeast distillery protein in substitution of traditional source of protein. (Table 1). The control ration was the commercial ration usually used by the fishery station to feed the fishes. Each of the rations treatment named (T) was given to three groups of fishes (triplicate).

The juveniles were randomly distributed in 12 groups of 6 individuals; each group was placed in cages with capacity for 100 liters, with continuos aeration and water exchange.

The cages were siphoned weekly to remove the residues and algae deposited on the bottom and on the walls. The fishes were daily observed in case of any uncommon behavior, morphological variation and death. Each ration was provided in pelleted form to three groups of fish (triplicate).

The juveniles were fed twice a day, at 8:00 and 17:00 in the proportion of $4 \%$ on the biomass of each cage, provided a feeding trough type, and the treatment held in the form guide. At the end of each biometrics fish was weighed (g) and measured $(\mathrm{cm})$ individually. 
Table 1 - Composition centesimal bromatologic of the experimental rations for the Nile tilapia (dry matter).

\begin{tabular}{|c|c|c|c|c|}
\hline Ingredients (\%) & Standar & Test & Test & Test \\
\hline Yeast & 0.00 & 20.00 & 40.00 & 60.00 \\
\hline Fish meal & 10.00 & 10.00 & 10.00 & 5.00 \\
\hline Wheat flour & 5.00 & 5.00 & 5.00 & 5.00 \\
\hline Corne meal & 44.35 & 35.36 & 25.14 & 11.76 \\
\hline Soybean flour & 38.65 & 26.64 & 14.86 & 10.00 \\
\hline Phosphate Bicalcic & 0.00 & 0.00 & 0.00 & 1.24 \\
\hline Vegetable oil & 0.00 & 1.00 & 3.00 & 5.00 \\
\hline Mineral supplement $^{1}$ & 1.00 & 1.00 & 1.00 & 1.00 \\
\hline Vitamine supplement $^{1}$ & 1.00 & 1.00 & 1.00 & 1.00 \\
\hline Total & 100.00 & 100.00 & 100.00 & 100.00 \\
\hline \multicolumn{5}{|c|}{ Calculated Composition } \\
\hline Dry matter (\%) & 88.54 & 89.07 & 89.72 & 90.37 \\
\hline $\mathrm{ED}(\mathrm{kcal} / \mathrm{kg})$ & 3136 & 3094 & 3112 & 3065 \\
\hline Fat $(\%)$ & 2.81 & 3.38 & 4.91 & 6.07 \\
\hline Crude fibre $(\%)$ & 3.96 & 3.01 & 2.04 & 1.45 \\
\hline Mineral matter $(\%)$ & 5.44 & 6.40 & 7.35 & 8.86 \\
\hline Total phosphorus $(\%)$ & 0.67 & 0.60 & 0.52 & 0.54 \\
\hline Crude protein $(\%)$ & 28.00 & 28.00 & 28.00 & 28.00 \\
\hline Calcium $(\%)$ & 0.77 & 0.74 & 0.71 & 0.70 \\
\hline
\end{tabular}

The water temperature was determined by a thermistor coupled to an oxygenmeter. Dissolved oxygen was measured by an oxygenmeter model Y55, pH by a electronic pHmeter model FI002. Conductivity was determined by an electronic conductmeter. Total alkalinity was measured by titration with sulphuric acid (Carmouse, 1994; Paranhos, 1996), ammonia by photometry by indophenol method as described by Paranhos (1996). Nitrite was determined using the classical spectrophometric method based on the Griess reaction (Carmouse, 1994). Orthophosphate determination was based on the reaction between this and molibdic acid, giving phosphomolibdic acid. After ascorbic acid reduction, he resulting blue compound was quantified by spectrophotometry.

The experimental method was entirely randomized with four treatments and three repetitions. The data were submitted to analysis variance and polynomial regression, using software statistcs. The development of the tilapias related to the different treatments was analyzed through the quantitative analysis of total weight/total length (Santos, 1978), feed conversion, efficiency index and survival (Ivlev, 1966), graphical expression of growth in total length, curves of biomass and production, (Weatherley and Gill, 1987; Medri et al., 2000).

\section{RESULTS AND DISCUSSION}

The average values of temperature $\left(22.21^{\circ} \mathrm{C} \pm 1.03^{\circ} \mathrm{C}\right), \mathrm{pH}(8.09 \pm 0.68)$, conductivity $(18.46 \pm 3.02 \mathrm{~S} / \mathrm{cm})$, dissolved oxygen of the water $(4.57 \pm 0.45 \mathrm{mg} / \mathrm{L})$, alkalinity $(290.42 \pm 55.36$ $\mathrm{mgCaCO} 3 / \mathrm{L})$, ammonia $(0.04 \pm 0.01 \mathrm{mg} / \mathrm{L})$ and nitrite $(0.18 \pm 0.02 \mathrm{mg} / \mathrm{L})$, obtained during the trial period, has remained within the range recommended by Sipauba-Tavares (1995), not influencing the performance of fish.

In Table 2, are the results for the average weight of tilapia in function of the inclusion increasing levels of proteins from yeast, distillery in the diet. Effect of the treatments $(p>0.05)$ on the survival and alimentary conversion. The result found in the present study agrees to the values found by Furuya (2000), and Ribeiro et al. (1996) stating that there was no effect of the treatments on the survival and alimentary conversion of the tilapias of the Nile. 
Table 2 - Average weight gain of fishes in function of inclusion distillery proteins yeast.

\begin{tabular}{lcccc}
\hline \multicolumn{5}{c}{ Weight (g) } \\
\hline Days & $\mathbf{0 \%}$ & $\mathbf{2 0 \%}$ & $\mathbf{4 0 \%}$ & $\mathbf{6 0 \%}$ \\
\hline 0 & $37.26 \pm 4.82$ & $37.65 \pm 5.07$ & $37.28 \pm 5.56$ & $36.90 \pm 5.78$ \\
28 & $46.34 \pm 5.72$ & $46.90 \pm 6.73$ & $47.40 \pm 6.12$ & $43.91 \pm 6.59$ \\
56 & $71.90 \pm 6.34$ & $73.56 \pm 7.02$ & $74.50 \pm 7.67$ & $67.90 \pm 7.65$ \\
84 & $95.70 \pm 7.89$ & $98.43 \pm 8.67$ & $96.80 \pm 8.70$ & $93.68 \pm 8.42$ \\
112 & $115.89 \pm 8.93$ & $120.52 \pm 9.51$ & $118.69 \pm 10.45$ & $114.97 \pm 9.48$ \\
\hline \multicolumn{5}{c}{ Data of consumption } \\
\hline Food conversion & 4.76 & 3.31 & 4.34 \\
Survival (\%) & 72.22 & 77.78 & 77.78 & 72.50 \\
\hline
\end{tabular}

* A quadratic effect over weight gain $\left(\mathrm{Y}=73.39+0.173 \mathrm{X}-0.0034 \mathrm{X}^{2} ; \mathrm{R}^{2}=0.9986\right)$.

With the increase in the levels of protein inclusion of distillery leavening, there was quadratic effect $\left(\mathrm{Y}=73.39+0.173 \mathrm{X}-0.0034 \mathrm{X}^{2} ; \mathrm{R}^{2}=0.9986\right)$ on weight gain of the tilapias of the Nile (Fig. 1), concluding that the best level of inclusion of yeast as a protein source in the diet for juvenile reversed from the Nile tilapia is $25.44 \%$. Furuya (2000), working with increasing levels of inclusion of dried yeast in treatments $(0.00,7.80,15.60,23.40$ and $31.20 \%$ ) in the diet, observed quadratic effect on the weight gain $(\mathrm{Y}=1.7133-0.0477 \mathrm{X}$ $0.0017 \mathrm{X}^{2}, \mathrm{R}^{2}=0.78$ ), having as optimum level of inclusion of dry leavening in the diet for reverted fingerling of tilapias of the Nile of $14 \%$.

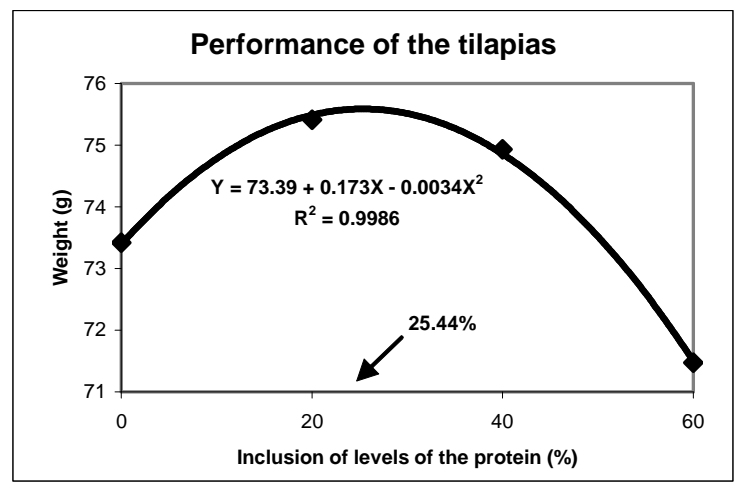

Figure 1 - Reverted weight of juveniles of the Nile tilapia in function of the inclusion of levels of the protein of leavening.

Works involving food tests for the tilapia of the Nile are sufficiently common for animals from the phase of fingerling (Boscolo et al., 2001; Meurer et al., 2005), demonstrating the possibility of proteinic food use of vegetable origin since the essential amino acid requirements are taken care of. However, for the phase sexual reversal they become sufficiently scarce.

Pezzato (1982), cited by Castagnolli (1992), substituted gradually meat flour by dry yeast at levels of $\mathrm{A}=0 \%, \mathrm{~B}=33.3 \%, \mathrm{C}=66.6 \%$ and $\mathrm{D}=100 \%$ and concluded that the treatments that received yeast were superior to the testimony and that the substitution of $33.3 \%$ of yeast was statistically the one that propitiated the best result.
Ribeiro et al. (1996), who worked with Nile tilapia to analyze the availability of the inclusion of increasing levels of sugarcane yeast, $(18,36,54$, $72,90 \%)$ included in the ratons in a period of 45 days, did not observe any statistically $(\mathrm{P}>0.05)$ significant difference.

Meurer et al. (2000). Evaluated the performance and consumption of ration for fingerlings of tilapia of the Nile reverted sexually, fed with rations I containing $0.00 ; 1.50 ; 3.00 ; 4.50$ and $6.00 \%$ of yeast of distillery, the dry method for of spray-dry. It noticed a linear increase $(\mathrm{P}<0.05)$ for the performance parameters and a linear reduction in alimentary conversion. The level of $6.00 \%$ of yeast in the ration provided the best performance. 
Alves et al. (1988) reported that the optimum level of substitution of soybean flour by yeast (Saccharomyces cerevisiae) for an increase of weight in Nile tilapias were $36.97 \%$. The results obtained were according to Cowey (1974), when compared the nutritional value of the yeast, and with Matty et al. (1978) who attributed the yeast digestibility of protein fraction similar to that of soybean meal and that rates above $40 \%$ of replacement imply a lesser development for trout.

Medri et al. (2005), working with increasing levels of inclusion of protein from yeast, distillery $(0,20$, 40 and 60\%) in floating net cages, observed quadratic effect $(\mathrm{Y}=183.58+0971 \mathrm{X}-0.0172 \mathrm{X} 2$; $\mathrm{R} 2=92.54 \%)$ on the gain of weight of the Nile tilapia, concluding that the best level of inclusion of yeast as a protein source in the diet for juvenile reversed from the Nile tilapia is $28.23 \%$. Not observed effects of the treatments $(p>0.05)$ on the length and feed. With respect to survival noted that the treatments $(20,40$ and $60 \%)$ were significantly higher $(\mathrm{p}<0.01)$ treatment $0 \%$.

Padua (1996) tested five levels $(0,25,50,75$, and $100 \%$ ), replacement of fishmeal by dry yeast from distillery as a source of protein and noted that up to $75 \%$ of replacement showed no adverse effect in productive performance and metabolism of juvenile pacu.

Davies and Wareham (1998) observed that the inclusion above $15 \%$ of leavening for tilapia (Oreochromis mossambicus) resulted in a gradual reduction in the value of the diet. For the Nile tilapia fingerlings, (Medri, et al., 2000), in experiment to evaluate levels of $0,10,20$ and $30 \%$ of the ration by the distillery yeast (Saccharomyces cerevisiae) in experimental diets showed no detrimental effect until the maximum level tested, $30 \%$.

The yeast has some factors that affect your animal use, as non-protein nitrogen content and the cell wall. These combined factors may be responsible for the performance of smaller fish fed large quantities of yeast, as observed by Furuya et al. (2000) and the best performance achieved with the addition of yeast, distillery probably occurred by better balancing of nutrients.

\section{Weight/length relation}

The constant value related to the growth form of the fish bodies $(\theta)$ was near to 3.0. According to Wootton (1990), the value $\theta=3.0$ indicated a isometric growth. A value higher than 3.0 meant that the fish became lighter on account to its growth in length. A value lower than 3.0 indicate that the fish became heavier because of the weight increase. Values close to these were found by Mainardes Pinto (1989), who worked with tilapias (Oreochromis. niloticus) growth.

The condition factor $(\phi)$ often used in studies of fishery biology, indicating the well being degree of the fishes in the environment they live to verify if they make good use of the ration (Weatherley and Gill, 1987).

The mathematical expressions of the curves of Weight/ Total Length, of tilapias and the linear transformation correspondent to the treatments 0 , 20, 40, and 60 show in Table 3.

The estimated values of the coefficient of linear correlation of Pearson were positive and near to 1(one), which indicates the high association degree among the variables of the logarithmic the adjustment expressions corroborating with the little dispersion observed of the empiric points to the theoretic curves.

Table 3 - The mathematical expressions of the graphics Weight/ Total Length, of tilapias and the linear transformation correspondent to the treatments $0,20,40$ and 60 .

\begin{tabular}{llcc}
\hline & & Weight $(\mathbf{W t}) /$ Total Length $(\mathbf{L t})$ & $\mathrm{r}_{\mathrm{xy}}$ \\
\hline$\%$ Yeast & $\mathrm{Wt}=\phi \mathrm{Lt}^{\theta}$ & $\ln \mathrm{Wt}=\ln \phi+\theta \operatorname{lnLt}$ & 0.9686 \\
0 & $\mathrm{Wt}=0.0233 \mathrm{Lt}^{2.89}$ & $\ln \mathrm{Wt}=-3.7593+2.89 \operatorname{lnLt}$ & 0.9740 \\
20 & $\mathrm{Wt}=0.0257 \mathrm{Lt}^{2.86}$ & $\ln \mathrm{Wt}=-3.6612+2.86 \operatorname{lnLt}$ & 0.9688 \\
40 & $\mathrm{Wt}=0.0220 \mathrm{Lt}^{2.91}$ & $\ln \mathrm{Wt}=-3.8167+2.91 \operatorname{lnLt}$ & 0.9709 \\
60 & $\mathrm{Wt}=0.0242 \mathrm{Lt}^{2.71}$ & $\operatorname{ln~Wt}=-3.7214+2.87 \operatorname{lnLt}$ & \\
\hline
\end{tabular}

\section{Curves of weight $(\mathrm{Wt})$ and length $(\mathrm{Lt})$}

There were no possibilities to calculate the growth curves of length and weight of the fishes in cages by the expression of Von Bertalanffy (1938), because there were no satisfactory adjust to the experiments information. The experimental model described by Weatherley and Gill (1987); Medri et al. (2000).

Curves of weight (Wt) and length (Lt) of the tilapias are shown in Figures 2 and 3, respectively. 


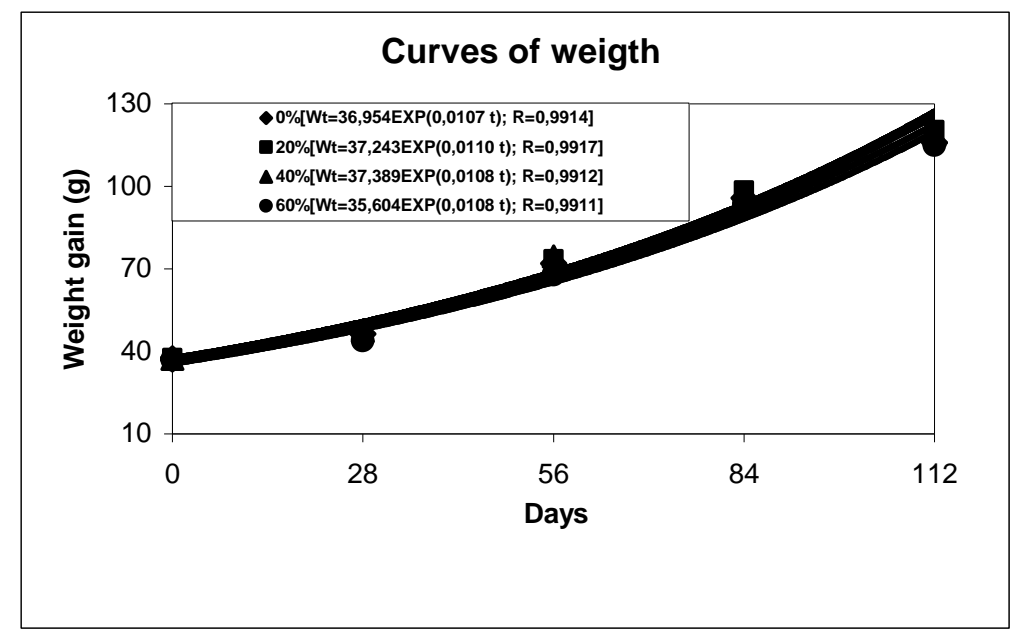

Figure 2 - Curve of weight ( $\mathrm{g}$ ) of the tilapias adjusted for the exponential model in treatments 0 , 20, 40 and $60 \%$.

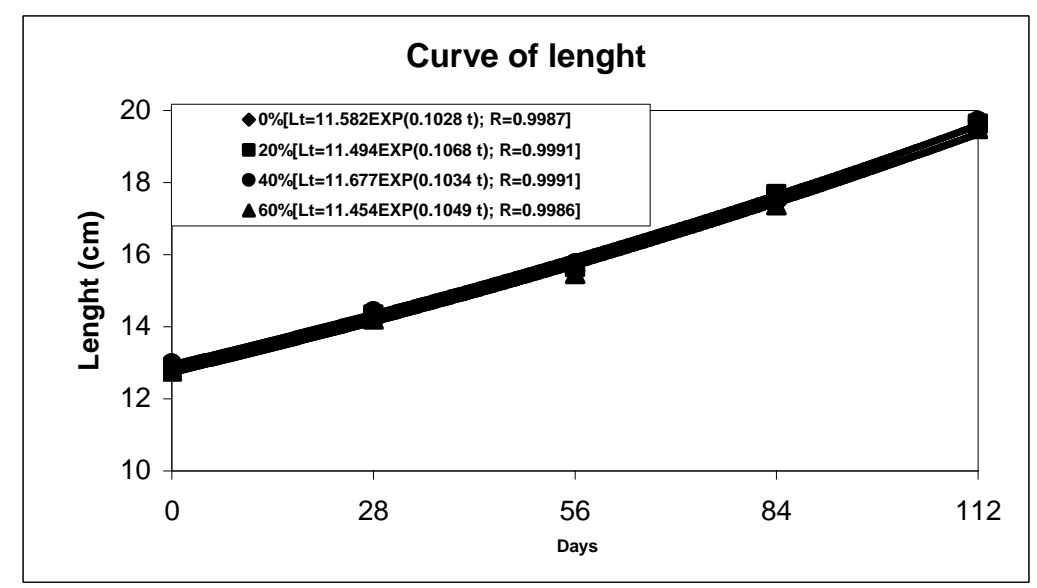

Figure 3 - Curve of lenght $(\mathrm{cm})$ of the tilapias adjusted for the exponential model in treatments 0 , 20,40 and $60 \%$.

\section{RESUMO}

Foram utilizados 72 juvenis de tilápia do Nilo (Oreochromis niloticus) sexualmente revertidos com peso médio inicial de $37.27 \pm 4.92 \mathrm{~g}$. distribuídos em 12 gaiolas de 100L para avaliar os efeitos da inclusão de levedura como fonte protéica na dieta. Os peixes foram distribuídos em um delineamento inteiramente casualizados com quatro tratamentos $(0 ; 20 ; 40$; e $60 \%)$ de proteína de levedura em substituição à proteína de fontes tradicionais com três repetições. Não foram observados efeitos dos tratamentos $(\mathrm{p}>0.05)$ sobre a sobrevivência e conversão alimentar. Foi observado efeito quadrático sobre o ganho de peso $\left(\mathrm{Y}=73.39+0.173 \mathrm{X}-0.0034 \mathrm{X}^{2} ; \mathrm{R}^{2}=0.9986\right)$. Concluiu-se que o melhor nível de inclusão de levedura como fonte protéica na dieta para juvenis revertidos de tilápias do Nilo é de $25.44 \%$.

\section{REFERENCES}

Alceste, C. and Jorry, D. E. (1998), Análisis de las tendencias actuales en la comercialización de tilapia en los Estados Unidos de Norteamérica y la Unión Europea. In: AQUICULTURA BRASIL. 10.. 1998. 
Recife. Anais... Recife: Associação Brasileira de Aqüicultura, 349-364.

Alves, L. M. C. G., Pezzato, L. E., Neto, A. C. G., Pezzato, A. C., Barros, M. M. and Padovani, C. R. (1988), Avaliação de níveis crescentes de levedura seca de vinhaça incorporadas às rações de Tilápia do nilo. In: Simpósio Latinoamericano de Aqüicultura. 6. Simpósio Brasileiro de Aqüicultura. 5. 1988. Florianópolis. Resumos... Florianópolis : Abraq. 355361.

Bertalanffy, L. Von. (1938), A quantitative theory of organic growth. Humman Biology, Detroit, 10 (2), 181-213.

Bombardelli, R. A. and Hayashi, C. (2005), Masculinization of larvae of Nile tilapia (Oreochromis niloticus L.) by immersion baths with alpha-methyltestosterone. R. Bras. Zootec. 34 (2), 365-372.

Booth, M.A.; Allan, G.L.; Frances, J. and Parkinson S (2001), Replacement of fish meal in diets for Australian silver perch. Bidyanus bidyanus IV. Effects of de-hulling and protein concentration on digestibility of grain legumes. Aquaculture. 196, 6785.

Boscolo, W. R.; Hayashi, C.; Meurer, F. and Soares, C. M. (2001), Farinhas de peixe, carne e ossos, vísceras e crisálida como atractantes em dietas para alevinos de tilápia do Nilo (Oreochromis niloticus). Revista Brasileira de Zootecnia. 30 (5), 1397-1402.

Butolo, J. E. (1997), Uso da levedura desidratada em alimentação animal: propriedades, custo relativo a outras formas de nutrientes. In: Produção De Biomassa De Levedura: Utilização em Alimentação Humana e Animal, 1997, Campinas. Anais... Campinas: ITAL, 70pp.

Campos-Ramos, R.; Harvey, S. C.; Mcandrew, B. J. and Penman D. J. (2003), An investigation of sex determination in the Mozambique tilapia, Oreochromis mossambicus, using synaptonemal complex analysis, FISH, sex reversal and gynogenesis. Aquaculture, 221, 125-140.

Carmouse, G. P. (1994), Metabolismo dos ecossistemas aquáticos: fundamentos teóricos, métodos de estudo e análise química/Gean Pirre Carmouse. - SP: Editora Edgard Brucher: Fapesp.

Castagnolli, N. (1992), Piscicultura de água doce. Jaboticabal: FUNEP, 189pp.

Cowey, C. B. (1974), Studies on the nutricion of marine Flat-flsh. The effect of dietary protein content on certain cell components and enzymes in the liver of Pleuronects platessa. MARS. BIOL, 28, 207-213.

Davies, S. J. and Wareham, H. A. (1998), A preliminary evaluation of an industrial single cell protein in practical diets for tilapia (Oreochromis mossambicus, Peters). Aquaculture, Amsterdam, 73, 189-199.

Desprez, D.; Géraz, E. and Hoareau, M.C. (2003), Production of a high percentage of male offspring with a natural androgen, 11 b hydroxyandrostenedione (11bOHA4), in Florida red tilapia. Aquaculture, 216, 55-65.

El-dahhar, A. A. and El-shazly, K. (1993), Effect of essential amino acids (methionine and lysine) and treated oil in fish diet on growth performance and feed utilization of Nile tilapia, Tilapia nilotica (L.). Aquaculture and Fisheries Management, 24(6), 731739.

Furuya, W. M.; Seron, S.; Vargas, L.; Hayashi, C.; Furuya, V. R. B. and Soares, C. M. (2000), Níveis de levedura "spray-dried" na dieta de alevinos revertidos de tilápia do Nilo (Oreochromis niloticus L.). Ciência Rural, Santa Maria, 30(4), 699-704.

Furuya, W. M.; Pezzato, L. E.; Pezzato, A. C.; Barros, M. M. and Miranda, E. C. (2001), Digestibility coefficients and digestible amino acids values of some ingredients for Nile tilapia (Oreochromis niloticus). Rev. Bras. Zootec., Viçosa, July/Aug. 2001, 30 (4), 1143-1149.

Furuya, W. M.; Neves, P. R.; Silva L. C. R.; Botaro, D.; Hayashi, C. and Sakaguti, E. S. (2004), Fitase na alimentação da tilápia do Nilo (Oreochromis niloticus),.durante o período de reversão de sexo. Acta Scientiarum, 26 (3), 299-303.

Ghiraldini, J. A. and Rossell, C. E. (1997), Caracterização e qualidade da levedura desidratada para alimentação animal. In: Simpósio sobre Tecnologia da Produção e Utilização na Alimentação Animal, 1997, Campinas, SP. Anais... Campinas: CBNA, 27-50.

Hayashi, C. (1995), Breves considerações sobre as tilápias. In Ribeiro, R.P.; Hayashi, C.; Furya, W.M. (Eds.) Curso de piscicultura - criação racional de tilápias. 1. ed. Maringá, 4pp.

Ivlev, V. S. (1996), The biological productivity of waters. J. Fish Res. Board. Can. 23(11), 1727-59.

Kikuchi, K. (1999), Use of deffated soybean meal as a substitute for fish meal in diets of Japanese flounder (Paralichthys olivaceus). Aquaculture, 179, 3-11.

Lovshin, L L. (1997), Tilápia farming: a growing worldwild aquaculture industry. In: Simpósio Sobre Manajo e Nutrição e Peixes, 1., 1997, Piracicaba. Anais... Piracicaba: Colégio Brasileiro de Nutrição Animal, 137pp.

Lovshin, L. L. and Cyrino, J. E. P. (1998), Status of commercial fresh water fish culture in Brazil.. In: Simpósio Sobre Manajo e Nutrição e Peixes, 2., 1998, Piracicaba. Anais...Piracicaba: Colégio Brasileiro de Nutrição Animal, 1pp.

Mainardes Pinto, C. S. R. (1989) Criação de tilápia. São Paulo: Instituto de Pesca, 13p. (Boletim Técnico, 10).

Matty, A. J. and Smith, P. (1978), Evaluation of a yeast, bacterium and alga as protein source for rainbowtrout. 1. Effect of protein level on growth, gross convertion efficiency and protein conversion efficiency. EIFAC/78/ SYMP., E/7. 
Medri, V.; Pereira, G .V. and Leonhardt, J. H. (2000), Growth of Nile Tilapia Oreochromis niloticus Fed With Different Levels of Alcohol Yeast. São Carlos: Revista Bras. Biol. 1, 113-121.

Medri, V.; Medri, W. and Caetano Filho, M. (2005), Desempenho das tilápias nilóticas (Oreochromis niloticus) alimentadas com diferentes níveis de proteínas de levedura de destilaria em tanques-rede. Acta Scientiarum (Animal Sciencies). Maringá, 27 (2), 221-227.

Meurer, F.; Hayashi, C.; Soares, C. M. and Boscolo, W. R. (2000), Utilização de levedura spray-dried na alimentação de alevinos de tilápia do Nilo (Oreochromis niloticus L.). Acta Scientiarum, 22 (2), 479-484.

Meurer, F. (2002), Cultivo de tilápias. In: Congresso Paranaense dos Estudantes de Zootecnia, Maringá. Anais... Maringá: Universidade Estadual de Maringá, [2002]. CD-ROM.

Meurer, F.; Hayashi, C. and Boscolo W. R. (2003), Digestibilidade aparente de alguns alimentos protéicos pela tilápia do Nilo (Oreochromis niloticus). Rev. Bras. Zootec. Viçosa, 32(6), 18011809.

Meurer, F. and Hayashi, C. (2003), Polissacarídeos nãoamilásceos na nutrição de peixes - Revisão. Arquivos de Medicina Veterinária e Zoologia da Unipar. Umuarama, 6(2), 127-138.

Meurer, F. Hayashi, C.; Boscolo, W. R.; Christiano R. S. and Robie A. B. (2005), Protein sources supplemented with amino acids and minerals to Nile tilapia during sex reversal phase. Rev. Bras. Zootec. Viçosa, 34 (1), 1-6.

Mukhopadhyay, N. and Ray, A. K. (1997), The apparent total and nutrient digestibility of sal seed (Shorea robusta) meal in rohu, Labeo rohita (Hamilton), fingerlings. Aquaculture Research, 28, 683-689.

Oliveira, A. C. B.; Cantelmo, O. A.; Pezzato, L. E. ; Rosaribeiro, M. A. and Barros, M. M. (1997), Coeficiente de digestibilidade aparente da torta de dendê e farelo de coco em pacu. Revista Unimar, 19(3), 897-903.

Pádua, D. M. C. (1996), Utilização da levedura alcoólica (Saccharomyces cerevisiae) como fonte protéica na alimentação de juvenis de pacu (Piaractus mesopotamicus, PISCES, TELEOSTEI): aspectos metabólicos e de desempenho produtivo. Jaboticabal, 120p. Dissertação (Mestrado). Centro de Aqüicultura da UNESP - Universidade Estadual Paulista.

Paranhos, R. (1996), Alguns métodos para análise da água. Rio de Janeiro: UFRJ, sub-reitoria e ensino de graduação e corpos discente/SR 1, 200p. il. (cadernos didáticos UFRJ;19).

Pereira-da-Silva, E. M. and Pezzato L. E. (2000), Respostas da tilápia do Nilo (Oreochromis niloticus) à atratividade e palatabilidade de ingredientes utilizados na alimentação de peixes. Revista Brasileira de Zootecnia. Viçosa, 29(5), 1273-1280.

Pezzato, L. E. (1982, Levedura de álcool como fonte protéica para carpa comum. In: 19 Reunião da SBZ, 1982, Piracicaba. Anais da 19 SBZ. Piracicaba,. (1), 269-270.

Refstie, S.; Svihus, B.; Shearer, K.D. and Storebakken T. (1999, Nutrient digestibility in Atlantic salmon and broiler chickens related to viscosity and non-starch polysaccharide content in different soybean products. Animal Feed Science and Technology, 79, 331-345.

Ribeiro R. P., Hayashi, C., Furuya, W. M., Furuya, V. R. B. and Soares, C. M., (1996), Utilização de diferentes níveis de levedura seca, Saccharomyces cerevisiae, em dietas para alevino de tilápias do nilo, Oreochomis niloticus, em cultivo monossexo. In: SIMPÓSIO BRASILEIRO DE AQÜICULTURA, 9, Sete Lagoas, 1996, 99p, Resumos... Sete Lagoas, Simbraq.

Santos, E.P. (1978), Dinâmica de populações aplicada à pesca e piscicultura. ed. Univ. São Paulo, Hucitec, $129 \mathrm{pp}$.

Scapinello, C.; Faria, H. G. and Furlan, A. C. (1996), Valor nutritivo da levedura de recuperação (Saccharomyces $\mathrm{sp}$ ), seca em rolo rotativo e pelo método spray-dry para coelhos em crescimento.. In: XXXIII Reunião Anual da SBZ, 1996, Fortaleza. Anais da XXXIII Reunião Anual da SBZ.

Scapinello, C.; Faria, H. G.; Furlan, A. C. ; Pedro, M. R. S.; Oliveira, P. B. and Machado, R. M. (1997), Desempenho de coelhos em crescimento com levedura de recuperação (Saccharomyces sp), seca pelo método spraydry. Revista Unimar, 19 (3), 913921.

Siddhuraju, P. and Becker, K. (2001), Preliminary nutritional evaluation of Mucuna seed meal (Mucuna pruriens var. utilis) in common carp (Cyprinus carpio L.): an assessment by growth performance and feed utilization. Aquaculture, 196, 105-123.

Silva, A. L. N. and Siqueira, A. T. (1997), Piscicultura em tanques-rede. Princípios básicos. Recife. Imprensa Universitária-UFRPE. 71pp.

Sipaúba-Tavares, L. H. S. (1995), Limnologia aplicada à aqüicultura. Jaboticabal: FINEP, 70pp.

Weatherley, A. H. and Gill, H. S. (1987), The biology of fish growth. London: Academic Press, 443pp.

Wootton, R. J. (1990), Ecology of teleosts fishes. Londom: Chapman and Hall, 404pp.

Wu, V. Y.; Rosati, R. R.; Sessa, D. J. B.; and Brown, P. B. (1995), Evaluation of corn gluten meal as a protein source in tilapia diets. J. Agric. Food Chem., 43, 1585-1588.

Received: November 20, 2006; Revised: May 03, 2007; Accepted: June 12, 2008. 